\title{
The Effect of Thionamide to TRH, TSH, IL-4, T-REG, and Anti-TPO in Graves' Disease
}

\author{
Eva Decroli*1, Dwitya Elvira² ${ }^{2}$ and Dinda Aprilia ${ }^{1}$
}

1. Endocrinology and Metabolic Subdivision, Division of Internal Medicine, Dr. M. Djamil General Hospital/ Medical Faculty of Andalas University, Padang, West Sumatera, Indonesia

2 Allergy and Immunology Subdivision, Division of Internal Medicine, Dr. M. Djamil General Hospital/ Medical Faculty of Andalas University, Padang, West Sumatera, Indonesia

Info Article
Submitted: 23-07-2019
Revised: 26-2-2019
Accepted: 13-3-2019
*Corresponding author
Eva Decroli
Email:
evadecroli@med.unand.ac.id

\section{Info Article}

ABSTRACT

Submitted: $23-07-2019$

Revised: $26-2-2019$

\section{INTRODUCTION}

The most common cause of hyperthyroidism in the world is Graves' disease. Graves' disease occurs in $2-2.5 \%$ of women and $0.2-0.6 \%$ of men. The factors that play a role in Graves' disease are environment, genetic disorders, and autoimmune processes. Thyroid-stimulating hormone (TSH) is one of the links in a complex signaling network that modulates and controls thyroid growth and function in Graves' disease. TSH not only works at glands and thyroid function. TSH circulating in the tissues is controlled by thyrotropin-releasing hormone (TRH) levels and the feedback effect of thyroid hormone levels on the tissues. In the immunological aspect of Graves' disease, at higher level, is controlled by T-regulator (T-reg) cells. In the next stage, the T-reg will differentiate T-helper (Th) cells which is will produce various inflammatory cytokines, including interleukin-4 (IL-4). In addition to T-reg cells, B cells have role in humoral to produce several antibodies, one of them is anti-TPO (LillevangJohansen et al., 2017; Wang et al., 2012; Elvira et al., 2017).

The stages of biosynthetic processes and secretions of thyroid hormones are stimulated by TSH. Thyroid hormone levels are controlled by TSH, which is produced by the anterior pituitary gland. TSH levels are regulated by TRH produced by the hypothalamus gland. Then, thyroid hormones will provide negative feedbacks to pituitary gland and hypothalamus (Davies et al., 2011)

Graves' disease is not only explained by the theories of comparison Th1 and Th2. Lately 
attention has been paid to T-reg cells. Initially Treg cells are described as CD4 + suppressor cells. Later, regulatory $\mathrm{T}$ cells (T-reg) are known as subtypes of CD4 which has specificities in the presence of CD25 expression, where the expression of the Forkhead box P3 (FOXP3) molecule is a special marker from T-reg. CD4 + CD25 + Foxp3 + Natural T-reg is considered as the main component of T-reg cells and emerges from the thymus as fully differentiated cells. And the abnormality of the T-reg number and its function has an effect on several autoimmune diseases (Elvira et al., 2017; Elvira et al., 2016)

Interleukin-4 is the main cytokine that associated with autoimmune thyroid disease. IL-4 plays a main role in the process of differentiating naïve $\mathrm{T}$ cells into $\mathrm{Th}$ cells and increasing the expression of MCH class II in B cells, dendritic cells and macrophage cells. IL-4 stimulates the isotype of Immunoglobulin G3 (IgG3-SCS) secreting cell which is associated with the severity of Graves' disease. The increase in cytokine values in Graves' patients illustrate the activity and interplay of Th1 and Th2 which are compatible with long-term inflammation and the damage process of the thyroid gland (Decroli et al., 2014).

Anti-thyroid peroxidase antibodies (antiTPO) are antibodies that bind to transmembrane proteins in tyrosite which are involved in the synthesis of thyroid hormones. Anti-TPO is also known as an microsomal anti-thyroid antibodies which is an important examination in autoimmune thyroid disease because it is found to be positive in more than $80 \%$ of patients with Graves' disease. There is some laboratory examination to describe hyperthyroid in Graves' disease, such as: Total T3, Total T4, FT3 and FT4. FT4 is an important laboratory examination because FT4 have longer half-life and not influenced by serum albumin levels. In addition, Wayne index that represented the symptoms and clinical manifestation including vital sign of Graves' disease is also important in assessing the patient's performance (Davies et al., 2011).

In general, the goal of treating hyperthyroidism in Graves' disease is to inhibit thyroid hormone secretion. One of the effective treatment for hyperthyroidism is antithyroid agents, which is thionamide. Antithyroid treatment consists of initial and maintenance therapy. Initial therapy is given until serum FT4 levels are normal. Initial therapy ranges from 4 to 12 weeks. After achieving normal serum FT4 levels, maintenance therapy begins by reducing the dose of thionamide by 50\% (Davies et al., 2011; Elvira et al., 2016; Decroli et al., 2014).

The Wayne index, serum FT4 and TSH levels are evaluated in the treatment of Graves' disease. Meanwhile, TRH levels have not been evaluated. The effect of therapy on Graves' disease should also influence the factors that play a role in immunological aspects, such as T-reg, IL-4, and anti-TPO. In this study, we want to see the effect of thionamide on levels of TRH, TSH, IL-4, T-reg, and anti-TPO in Graves' disease (Davies et al., 2011; Elvira et al., 2016; Decroli et al., 2014).

\section{MATERIAL AND METHODS}

This study is a clinical trial study with pre and post treatment to the study sample. This study involved 25 patients with Graves' disease who had not received prior treatment and who controlled to the metabolic endocrine clinic at the RSUP Dr. M. Djamil Padang who has signed the informed consent. Pregnant patients, allergic to thionamide, and Graves' relapse were excluded. All study participants were given initial therapy for three months of thionamide antithyroid treatment, PTU $300 \mathrm{mg}$. All blood samples have taken from this study participants for laboratory tests at the beginning and at the end of initial therapy. We examined variables like serum TRH, TSH, IL-4, Treg FOXP3 gene polymorphism, and anti-TPO levels. This research has received an ethical approval from the Ethics Committee of Medical Faculty of Andalas University.

\section{Methods}

Serum TRH, TSH, IL-4, T-reg FOXP3, and anti-TPO levels were examined with enzymelinked immunosorbent assay techniques (ELISA) method. The variables examinations were using Elabscience Biotechnology experimental kits.

There are several steps in this examination process. Add $100 \mu \mathrm{L}$ sample each well. Incubate for 90 minutes at $37^{\circ} \mathrm{C}$. Remove the liquid. Add $100 \mu \mathrm{L}$ Biotinylated Detection Ab. Incubate for one hour at $37^{\circ} \mathrm{C}$. Aspirate and wash 3 times. Add $100 \mu \mathrm{L}$ HRP Conjugate. Incubate for $30 \mathrm{~min}$ at $37^{\circ} \mathrm{C}$. Aspirate and wash 5 times. Add $90 \mu \mathrm{L}$ Substrate Reagent. Incubate for $15 \mathrm{~min}$ at $37^{\circ} \mathrm{C}$. Add $50 \mu \mathrm{L}$ Stop Solution. Read at $450 \mathrm{~nm}$ immediately. And then, calculate the results.

Statistical analysis was carried out by comparing serum TRH, TSH, IL-4, T-reg FOXP3 gene polymorphism, and anti-TPO levels at the beginning and at the end of three months therapy of thionamide. Paired t-test was used to analyze 
Table I. Baseline Characteristics

\begin{tabular}{|c|c|c|c|}
\hline Characteristics $(n=25)$ & Mean (SD) & Median & n (\%) \\
\hline Average Age (yo) & $27.48(5.6)$ & & \\
\hline \multicolumn{4}{|l|}{ Sex } \\
\hline Male & & & $1(4 \%)$ \\
\hline Female & & & $24(96 \%)$ \\
\hline Heart Rate (beats/minute) & $110.40(6.63)$ & & \\
\hline Systolic Blood Pressure (mmHg) & $139.48(6.63)$ & & \\
\hline Diastolic Blood Pressure (mmHg) & $63.48(8.64)$ & & \\
\hline Pulse Pressure (mmHg) & $76.00(11.77)$ & & \\
\hline Temperature $\left({ }^{\circ} \mathrm{C}\right)$ & $37.62(0.51)$ & & \\
\hline Wayne Index & $23.44(1.4)$ & & \\
\hline FT4 (pmol/L) & $55.55(17.98)$ & & \\
\hline TRH (mU/L) & & 92.589 & \\
\hline $\mathrm{TSH}(\mathrm{pg} / \mathrm{mC})$ & & 0.041 & \\
\hline T-reg FOXP3 gene polymorphism $(\mathrm{ng} / \mathrm{mL})$ & $0.621(0.23)$ & & \\
\hline $\mathrm{IL}-4(\mathrm{pg} / \mathrm{mL})$ & $19.759(7.03)$ & & \\
\hline Anti-TPO (pg/mL) & $2697.539(479.72)$ & & \\
\hline
\end{tabular}

Table II. Changes in vital signs at initial and after three months of thionamide therapy

\begin{tabular}{lccc}
\hline \multirow{2}{*}{ Variable } & \multicolumn{2}{c}{ Mean } & p \\
\cline { 2 - 3 } & Initial (n=25) & After three months (n=25) & 0.001 \\
Heart Rate (beats/minute) & $110.40(6.63)$ & $82.12(5.07)$ & 0.001 \\
Systolic Blood Pressure (mmHg) & $139.48(6.63)$ & $121.12(5.39)$ & 0.001 \\
Diastolic Blood Pressure (mmHg) & $63.48(8.64)$ & $77.32(6.38)$ & 0.001 \\
Pulse Pressure (mmHg) & $76.00(11.77)$ & $43.80(9.55)$ & 0.069 \\
Temperature $\left({ }^{\circ} \mathrm{C}\right)$ & $37.62(0.51)$ & $36.87(0.28)$ & \\
\hline
\end{tabular}

the differences of before and after the three months therapy. A value of $\mathrm{p}<0.05$ was considered as significant.

\section{RESULT AND DISCUSSION}

The baseline characteristics of this study (Table I). From the study, the range of patients' age are from 17 to 33 years, with the average of age is 27.48 (5.6) years. The number of female patients in this study is more than male patients, with percentage of women are $96 \%$ and men are $4 \%$. In this study, only one from the men patients was attended at the study. The average of age from this study's sample is smaller than some other studies. The average of age was obtained in this study is appropriate with The Indonesian Society of Endocrinology Task Force on Thyroid Diseases (2012) which states that Graves' disease appears more frequently at the third and fourth of decades (The Indonesian Society of Endocrinology, 2012; Voskuhl, 2011).
The higher percentage of women than men was also found by Voskuhl (2011). Voskuhl (2011) states that women are more prone to suffer from autoimmune disorders. This is in accordance with Ngo et al (2014) which states that autoimmune disorders are more common in women. There are several studies that gave the prevalence of autoimmune disorders in several countries. Carle et al (2011), Gaujoux et al (2006), Guo et al (2013), and Phitayakorn et al (2013) reported that Graves' disease was more prevalent among women in the United States, France, Denmark, and China. The Indonesian Society of Endocrinology Task Force on Thyroid Diseases (2012) states that the ratio of women to men with Graves' disease is 8:1 (The Indonesian Society of Endocrinology, 2012; Voskuhl, 2011; Ngo et al., 2014).

Changes in vital signs, Wayne index and serum FT4 levels at initial and after three months of thionamide therapy (Table II and Table III). 
Table III. Changes in Wayne index and FT4 serum levels at initial and after three months of thionamide therapy

\begin{tabular}{llll}
\hline \multirow{2}{*}{ Variable } & \multicolumn{1}{c}{ Mean } & p \\
\cline { 2 - 3 } & Initial (n=25) & After three months (n=25) & 0.001 \\
Wayne index & $23.44(1.42)$ & $11.80(1.47)$ & 0.001 \\
FT4 Serum (pmol/L) & $55.55(17.98)$ & $9.44(2.67)$ & \\
\hline
\end{tabular}

Table IV. Changes in TRH and TSH serum levels at initial and after three months of thionamide therapy

\begin{tabular}{llll}
\hline \multirow{2}{*}{ Variable } & \multicolumn{1}{c}{ Median } & p \\
\cline { 2 - 3 } & Initial (n=25) & After three months (n=25) & 0.001 \\
TRH Serum (pg/mL) & 92.589 & 115.944 & 0.001 \\
TSH Serum (mU/L) & 0.041 & 0.223 & 0.23 \\
\hline
\end{tabular}

Tabel V. Changes in serum T-reg FOXP3 polymorphism, IL-4 and anti-TPO levels at initial and after three months of thionamide therapy

\begin{tabular}{llll}
\hline \multirow{2}{*}{ Variable } & \multicolumn{1}{c}{ Mean } & p \\
\cline { 2 - 3 } & Initial (n=25) & After three months (n=25) & 0.124 \\
T-reg FOXP3 gene polymorphism (ng/mL) & $0.621(0.23)$ & $0.518(0.25)$ & 0.150 \\
IL-4 (pg/mL) & $19.759(7.03)$ & $23.040(7.35)$ & 0.361 \\
Anti-TPO $(\mathrm{pg} / \mathrm{mL})$ & $2697.539(479.72)$ & $2604.710(458.80)$ & 0 \\
\hline
\end{tabular}

Heart rate, systolic blood pressure, and pulse pressure are decreased after initial thionamide therapy. But, there is no significant changes in temperature. The decreased of Wayne index and serum FT4 levels are statistically significant. These showed that initial therapy of thionamide can improve the patient's performance. Davies et al (2011) also found that initial therapy of thionamide will decreased nervousness, palpitation and heart rate, increased strength, and weight gain. The decreased of these parameters are important to evaluate the outcome of therapy (Davies et al., 2011).

Changes in serum TRH and TSH levels at initial and after three months of thionamide therapy (Table IV). Median of serum TSH level before administration of thionamide in this study was $0.041 \mathrm{mU} / \mathrm{l}$. After giving thionamide for three months, the median of serum TSH level was 0.223 $\mathrm{mU} / \mathrm{L}$. There was an increase in serum TSH level after administration of thionamide for three months, statistically significant. This result is supported by Schimdt and Braunbeck (2011) who stated that zebrafish who get thionamide will experience thyroid gland hyperplasia and increased blood vessel flow in the thyroid gland tissue. Immunohistological staining at cells which are producing $\mathrm{TSH}$ in the pituitary shows a significant increase. This indicates that an increase occurs in serum TSH levels of zebrafish after the administration of thionamide (Schmidt et al., 2011).

Median serum TRH level before administration of thionamide in this study was $92.589 \mathrm{pg} / \mathrm{mL}$. After giving thionamide for three months, the median serum TRH level was 115.944 $\mathrm{pg} / \mathrm{mL}$ There was an increase in TRH levels after the administration of thionamide for three months, which is statistically significant. Propylthiouracil is effective in reducing thyroid hormone levels back to normal with the initial therapy for three months. This decrease in thyroid hormone levels will be followed not only by increased in TSH levels, but also by an increase in TRH levels through the hypothalamic-pituitary-thyroid axis. (Alkemade, 2015; Guissouma et al., 2002).

Changes in serum T-reg FOXP3 polymorphism serum, IL-4 and anti-TPO levels at initial and after three months of thionamide therapy (Table V). The mean T-reg FOXP3 polymorphism before administration of thionamide in this study was $0.621 \mathrm{ng} / \mathrm{ml}$. After giving thionamide for three months, the average $\mathrm{T}$ reg FOXP3 polymorphism in this study was $0.518 \mathrm{ng} / \mathrm{mL}$. The change in FOXP3 T-reg polymorphism statistically was not significant. 
The mean serum IL-4 level before administration of thionamide in this study was $19.759 \mathrm{pg} / \mathrm{mL}$. After giving thionamide for three months, the mean serum IL-4 level in this study was $23,040 \mathrm{pg} / \mathrm{mL}$. This change in IL-4 levels statistically was not significant. The mean serum anti-TPO level before administration of thionamide in this study was 2,697,539 pg/mL. After giving thionamide for three months, the mean serum anti-TPO level in this study was 2,604,710 pg/mL. This change in the level of anti-TPO statistically was not significant.

Humar et al (2008) explained that thionamide is an antithyroid drug with immunomodulating effects. This was proven in his research that showed thionamide which inhibited the synthesis of proinflammatory cytokines TNF- $\alpha$ and interferon- $\lambda$. Decroli et al (2014) found that administration of thionamide for one year would reduce IL-4 levels. Levels of IL-4 were found to drop dramatically in the first six months of thionamide therapy. However, the influences of thionamide on T-reg and anti-TPO has not been widely discussed (Decroli et al., 2014; Humar et al., 2008).

This study shows that the administration of initial therapy of thionamide for three months will improve Graves' disease hormonally, which are normal levels of FT4, significantly increased TSH and TRH serum levels. In this study, there were no significant changes in the FOXP3 T-reg gene polymorphism, IL-4 levels, and anti-TPO serum. It explains that the importance to continue the administration of thionamide in Graves' disease to see its immunological effects (Elvira et al., 2017; Decroli et al., 2014; Lauberg et al., 2014).

\section{CONCLUSION}

The administration of thionamide in Graves' disease for three months will significantly decrease Wayne index and serum FT4 levels, increase serum TRH and TSH levels.

\section{ACKNOWLEDGEMENT}

This research was funded by Andalas University (UNAND) through LPPM. This research included in Klaster Riset Penelitian Percepatan ke Guru Besar - Penelitian Dasar Unggulan (KRP2GBPDU) UNAND 2018.

\section{REFERENCES}

Alkemade A., 2015, 'Thyroid hormone and the developing hypothalamus'. Front Neuroanat. 9(15), 1-9.
Davies T., Laurberg P., and Bahn R., 2011, 'Hyperthyroid Disorders', in Melmed $\mathrm{S}$, Polonsky K, Larsen R, Kronenberg H, Williams Textbook of Endocrinology, pp. 369-415, Elsevier.

Decroli E., Manaf A., and Syahbuddin S., 2014, 'Immunologic and hormonal effects of propylthiouracil treatment using maintenance dose in Graves' disease', Acta Med Indones. 46(4), 314-319.

Elvira D., and Darwin E., 2017, 'Role of proinflammatory and regulatory cytokines in pathogenesis of Graves' disease in association with autoantibody thyroid and regulatory FoxP3 T-cells', International Journal of Medical and Health Sciences. 11(3), 69-72.

Elvira D., 2016, 'The role of T-regulatory expression in autoimmune thyroid disease and its association with thyroid antibody', Journal of Autoimmune Disorders. 2(2), 19.

Guissouma H., Dupre SM., Becker, N., Jeannin E., Seugnet I., and Desvergne B., 2002, 'Feedback on hypothalamic TRH transcription is dependent on thyroid hormone receptor $\mathrm{N}$ terminus', $\mathrm{Mol}$ Endocrinol. 15(7), 1652-66.

Humar M., Dohrmann H., Stein P., Andriopoulos N., Goebel U. And Roesslein, M., 2008, 'Thionamides inhibit the transcription factor nuclear factor- $\kappa \mathrm{B}$ by suppression of Rac1 and inhibitor of $\kappa \mathrm{B}$ kinase $\alpha^{\prime}, J$ Pharmacol Exp Ther. 324(3), 1037-44.

Laurberg P., Nygaard B., Andersen S., Carle A., Karmisholt J., Kerjbjerg, A., et al., 2014, 'Association between TSH-receptor autoimmunity, hyperthyroidism, goitre, and orbitopathy in 208 patients included in the remission induction and sustenance in Graves' disease study', J Thyroid Res, 1-6.

Lillevang-Johansen M., Abrahamsen B., Jorgensen, H., Brix T., and Hegedus, 2017, 'Excess mortality in treated and untreated hyperthyroidism is related to cumulative periods of low serum TSH', J Clin Endocrinol Metab. 102(7), 2301-2309.

Ngo ST., Steyn FJ., and McCombe PA., 2014, 'Gender differences in autoimmune disease', Front Neuroendocrinol. 35(3), 347-69.

Schmidt F., and Braunbeck T., 2011. 'Alterations along the hypothalamic-pituitary-thyroid axis of the zebrafish (Daniorerio) after exposure to propylthiouracil', J Thyroid Res. 2011. 
The Indonesian Society of Endocrinology, 2012, 'Indonesian clinical practice guidelines for hyperthyroidism', Journal of the ASEAN Federation of Endocrine Societies. 27(1), 1-5.

Voskuhl R., 2011, 'Sex differences in autoimmune diseases', Biol Sex Differ. 2(1), 1.
Wang PW., Chen IY., Juo SH., Hsi E., Liu RT., and Hsieh CJ., 2012, 'Genotype and phenotype predictors of relapse of Graves' disease after antithyroid drug withdrawal'. Eur Thyroid J. $1,251-258$ 